\title{
Discontinuity and R-weak commutativity in fixed point consideration on non complete fuzzy metric spaces
}

\author{
*Praveen Kumar Sharma, **Sanjay Choudhary and ***Kamal Wadhwa \\ *Department of Mathematics, IES, IPS Academy, Rajendra Nagar, A.B. Road, \\ Indore - 452012 (M.P.), India \\ E-mail: praveen_jan1980@ rediffmail.com \\ **Professor and head department of Mathematics, Govt. Narmada \\ Mahavidhyalaya, Hoshangabad (M.P.), India \\ E-mail: bpi253636@yahoo.com \\ ***Asst. Professor of Mathematics, Govt. Narmada Mahavidhyalaya, \\ Hoshangabad (M.P.), India \\ E-mail: wadhwakamal68@gmail.com
}

\begin{abstract}
In this paper we prove common fixed point theorem under the condition of Rweak commutativity without taking any function continuous. We extend results of Sharma and Deshpande.
\end{abstract}

Mathematics Subject Classification: 47H10, 54H25

Keywords: Complete fuzzy metric space, continuous $t$-norm, fuzzy metric space, non complete fuzzy metric space, $R$-weak commutativity.

\section{Introduction}

In concept of fuzzy sets was introduced initially by Zadeh [42] in 1965. Since then to use this concept in topology and analysis many authors have expansively developed the theory of fuzzy sets and applications. Especially, Deng [6], Erceg [7], Kaleva and Seikkala [22], Krarmosil and Michalek [24] have introduced the concept of fuzzy metric spaces indifferent way. Recently many authors have also 
studied the fixed point theory in these fuzzy metric spaces ([1], [2], [8], [10],[11], [15], [16], [25], [37], [39]).

Mishra et al. [25] proved a common fixed point theorem on complete fuzzy metric spaces, which generalized, extended, and fuzzified several known fixed point theorems for contractive type maps on metric and other spaces. They assumed continuity of one map in each of two pairs of compatible maps and also three commutativity of continuous maps.

Cho et al. [4] extended, generalized and fuzzified several fixed point theorems on metric spaces, Menger probabilistic metric spaces, uniform spaces and fuzzy metric spaces ([10], [13], [14], [17], [18], [20], [25], [27], [28], [29], [33], [35]). In their main result they proved common fixed point theorem on complete fuzzy metric spaces. They assumed continuity of one map in each of two pairs of compatible maps of type (B) and also the commutativity of continuous maps. The result of Cho. et. all [4] was extended by Sharma and Deshande [39]. Cho [3] also extended, generalized and fuzzified some known results in fuzzy metric spaces metric spaces probabilistic metric spaces and uniform spaces ([10], [17], [20], [25], [28], [32]). He proved a common fixed point theorem for mappings under the condition of continuity and compatibility of type $(\alpha)$ on complete fuzzy metric spaces. Sharma [38] extended the main result of Cho [3].

Sharma and Deshpande [33] improved the results of Mishra et al. [25], Cho et al. [4], Cho [3], Sharma [38], Sharma and Despande [39]. They proved some common fixed point theorems in FM spaces by removing the assumption of continuity relaxing the condition of on compatibility of type $(\alpha)$ or compatibility of type $(\beta)$ to weak compatibility and replacing the completeness of the space with a set of alternative conditions.

In this paper we prove common fixed point theorem under the condition of Rweak commutativity without taking any function continuous. We extend results of Sharma and Deshpande [33].

\section{Preliminary Notes}

Definition 2.1:[30] A binary operation *: $[0,1] \times[0,1] \rightarrow[0,1]$ is called a continuous t-norm if $([0,1], *)$ is an abelian topological monoid with the unit-1 such that $\mathrm{a} * \mathrm{~b} \leq \mathrm{c} * \mathrm{~d}$ whenever $\mathrm{a} \leq \mathrm{c}$ and $\mathrm{b} \leq \mathrm{d}$ for all $\mathrm{a}, \mathrm{b}, \mathrm{c}, \mathrm{d} \in[0,1]$.

Examples of $\mathrm{t}-$ norm are $\mathrm{a} * \mathrm{~b}=\mathrm{ab}$ and $\mathrm{a} * \mathrm{~b}=\min \{\mathrm{a}, \mathrm{b}\}$

Definition 2.2: [24] the 3-tuple (X, M, *) is called a fuzzy metric space (shortly FM- space) if $\mathrm{X}$ is an arbitrary set, * is a continuous t-norm and $\mathrm{M}$ is a fuzzy set in $\mathrm{X}^{2} \times[0, \infty)$ satisfying the following conditions for all $\mathrm{x}, \mathrm{y}, \mathrm{z} \in \mathrm{X}$ and $\mathrm{t}, \mathrm{S}>0$.

(FM-1) $\mathrm{M}(\mathrm{x}, \mathrm{y}, 0)=0$

(FM- 2) $M(x, y, t)=1$ for all $t>0$ if and only if $x=y$,

$(\mathrm{FM} \mathrm{-3}) \mathrm{M}(\mathrm{x}, \mathrm{y}, \mathrm{t})=\mathrm{M}(\mathrm{y}, \mathrm{x}, \mathrm{t})$,

$(\mathrm{FM}-4) \mathrm{M}(\mathrm{x}, \mathrm{y}, \mathrm{t}) * \mathrm{M}(\mathrm{y}, \mathrm{z}, \mathrm{s}) \leq \mathrm{M}(\mathrm{x}, \mathrm{z}, \mathrm{t}+\mathrm{s})$,

$(\mathrm{FM}-5) \mathrm{M}(\mathrm{x}, \mathrm{y},):.[0, \infty) \rightarrow[0,1]$ is left continuous. 
(FM -6) $\lim _{\mathrm{t} \rightarrow \infty} \mathrm{M}(\mathrm{x}, \mathrm{y}, \mathrm{t})=1 \quad \forall \mathrm{x}, \mathrm{y}, \in \mathrm{X}$.

In what follows, $(X, M, *)$ will denote a fuzzy metric space, note that $M(x, y, t)$ can be thought as the degree of nearness between $\mathrm{x}$ and $\mathrm{y}$ with respect to $\mathrm{t}$. We identify $\mathrm{x}=\mathrm{y}$ with $\mathrm{M}(\mathrm{x}, \mathrm{y}, \mathrm{t})=1$ for all $\mathrm{t}>0$ and $\mathrm{M}(\mathrm{x}, \mathrm{y}, \mathrm{t})=0$ with $\infty$ and we can fine some topological properties and examples of fuzzy metric spaces in [9]. In the following example, we know that every metric induces a fuzzy metric.

Example- 2.1: [9] Let $(X, d)$ be a metric space. Define $a * b=a b$ or $a * b=\min \{a$, b $\}$ and for all $\mathrm{x}, \mathrm{y} \in \mathrm{X}$ and $\mathrm{t}>0$.

$$
\mathrm{M}(\mathrm{x}, \mathrm{y}, \mathrm{t})=\frac{t}{t+d(x, y)}
$$

Then $(\mathrm{X}, \mathrm{M}, *)$ is a fuzzy metric space. We call this fuzzy metric $\mathrm{M}$ induced by the metric $d$ the standard fuzzy metric. On the other hand, note that there exists no metric on X satisfying (i).

Now we give an example of a fuzzy metric space.

Example 2.2: Let $X=$ Set of real numbers. Define $a * b=a b$ or $a * b=\min \{a, b\}$ and for all $\mathrm{x}, \mathrm{y} \in \mathrm{X}$ and $\mathrm{t}>0$,

$$
\mathrm{M}(\mathrm{x}, \mathrm{y}, \mathrm{t})=\left[e^{\frac{|x-y|}{t}}\right]^{-1}
$$

Then $(\mathrm{X}, \mathrm{M}, *)$ is a fuzzy metric space.

Proof: (1) $\mathrm{M}(\mathrm{x}, \mathrm{y}, 0)=\left[e^{\frac{|x-y|}{0}}\right]^{-1}$

$$
=\left[\mathrm{e}^{\infty}\right]^{-1}=[\infty]^{-1}=1 / \infty=0
$$

Thus $\mathrm{M}(\mathrm{x}, \mathrm{y}, 0)=0$

(2) $\forall$ t $>0$, assume that $x=y$.

$\Rightarrow \mathrm{x}-\mathrm{y}=0$,

$\Rightarrow|\mathrm{x}-\mathrm{y}|=0$

$\Rightarrow \frac{|x-y|}{t}=0$

$\Rightarrow \quad\left[e^{\frac{|x-y|}{t}}\right]^{-1}=\left[\mathrm{e}^{0}\right]^{-1}$

$\Rightarrow \mathrm{M}(\mathrm{x}, \mathrm{y}, \mathrm{t})=1$ using (ii)

Therefore, if $\forall \mathrm{t}>0, \mathrm{x}=\mathrm{y}$ then $\mathrm{M}(\mathrm{x}, \mathrm{y}, \mathrm{t})=1$.

Conversely suppose that $\mathrm{M}(\mathrm{x}, \mathrm{y}, \mathrm{t})=1$.

$$
\Rightarrow\left[e^{\frac{|x-y|}{t}}\right]^{-1}=1
$$


$\begin{aligned} \Rightarrow & \mathrm{e}^{\frac{|x-y|}{t}}=\mathrm{e}^{0} \forall \mathrm{t}>0 . \\ \Rightarrow & \frac{|x-y|}{t}=0 \\ \Rightarrow & |x-y|=0 \forall \mathrm{t}>0 \text { implies that } \mathrm{x}=\mathrm{y} \text {. Therefore } \mathrm{M}(\mathrm{x}, \mathrm{y}, \mathrm{t})=1 \text { if and only if } \mathrm{x}\end{aligned}$ $=\mathrm{y}$.

(3) To prove $M(x, y, t)=M(y, x, t)$

We know that $|\mathrm{x}-\mathrm{y}|=|\mathrm{y}-\mathrm{x}| \quad \forall \mathrm{x}, \mathrm{y} \in \mathrm{R}$.

Now; $\mathrm{M}(\mathrm{x}, \mathrm{y}, \mathrm{t})=\left[e^{\frac{|x-y|}{t}}\right]^{-1} \quad$ using (ii)

$$
\begin{aligned}
& =\left[e^{\left.\frac{|y-x|}{t}\right]^{-1}}\right. \\
& =\mathrm{M}(\mathrm{y}, \mathrm{x}, \mathrm{t})
\end{aligned}
$$

Therefore $\mathrm{M}(\mathrm{x}, \mathrm{y}, \mathrm{t})=\mathrm{M}(\mathrm{y}, \mathrm{x}, \mathrm{t}) \quad \forall \mathrm{x}, \mathrm{y} \in \mathrm{X}$ and $\forall \mathrm{t}>0$.

(4) To prove $M(x, y, t) * M(y, z, s) \leq M(x, z, t+s)$.

We know that $\forall \mathrm{x}, \mathrm{y}, \mathrm{z} \in \mathrm{X},|\mathrm{x}-\mathrm{z}| \leq|\mathrm{x}-\mathrm{y}|+|\mathrm{y}-\mathrm{z}|$

So we have; $\forall \mathrm{x}, \mathrm{y}, \mathrm{z} \in \mathrm{X}$ and $\forall \mathrm{t}, \mathrm{s}>0$

$|\mathrm{x}-\mathrm{z}| \leq \frac{(t+s)}{t}|x-y|+\frac{(t+s)}{s}|y-z|$

$\Rightarrow \frac{|x-z|}{t+s} \leq \frac{|x-y|}{t}+\frac{|y-z|}{s}$

Thus $\mathrm{e}^{\frac{|x-z|}{t+s}} \leq \mathrm{e}^{\frac{|x-y|}{t}} \mathrm{e}^{\frac{|y-z|}{s}}$

$\left[e^{\frac{|x-z|}{t+s}}\right]^{-1} \geq\left[e^{\frac{|x-y|}{t}}\right]^{-1} *\left[e^{\frac{|y-z|}{s}}\right]^{-1}$

$\Rightarrow \mathrm{M}(\mathrm{x}, \mathrm{z}, \mathrm{t}+\mathrm{s}) \geq \mathrm{M}(\mathrm{x}, \mathrm{y}, \mathrm{t}) * \mathrm{M}(\mathrm{y}, \mathrm{z}, \mathrm{s})$

(5) To prove $\mathrm{M}(\mathrm{x}, \mathrm{y},):.[0, \infty) \rightarrow[0,1]$ is left continuous.

Take a sequence $\left\{\mathrm{t}_{\mathrm{n}}\right\} \in[0, \infty)$ such that the sequence $\left\{\mathrm{t}_{\mathrm{n}}\right\}$ converges to $\mathrm{t} \in[0, \infty)$ that is $\lim _{n \rightarrow \infty}\left|t_{n}-t\right|=0$.

Since the function $\mathrm{e}^{\mathrm{x}}$ is continuous on $\mathrm{R}$ we have $\mathrm{e}^{\frac{|x-y|}{t_{n}}}$ converges to $\mathrm{e}^{\frac{|x-y|}{t}}$ as $t_{n}$ converges to $t$. Therefore $M(x, y,):.[0, \infty) \rightarrow[0,1]$ is continuous.

(6) To prove $\lim _{t \rightarrow \infty} M(x, y, t)=1$.

Using (ii) $\mathrm{M}(\mathrm{x}, \mathrm{y}, \mathrm{t})=\left[e^{\frac{|x-y|}{t}}\right]^{-1}$

Taking the limit $\mathrm{n} \rightarrow \infty$, we have, $\lim _{\mathrm{t} \rightarrow \infty} \mathrm{M}(\mathrm{x}, \mathrm{y}, \mathrm{t})=\lim _{\mathrm{t} \rightarrow \infty}\left[e^{\frac{|x-y|}{t}}\right]^{-1}$ 
$\Rightarrow \quad \lim _{\mathrm{t} \rightarrow \infty} \mathrm{M}(\mathrm{x}, \mathrm{y}, \mathrm{t})=1$.

$$
\begin{aligned}
& =\left[e^{\frac{|x-y|}{\infty}}\right]^{-1} \\
& =\left[\mathrm{e}^{0}\right]^{-1}=[1]^{-1}=1
\end{aligned}
$$

Hence $(\mathrm{X}, \mathrm{M}, *)$ is a fuzzy metric space.

Lemma 2.1: [10] For all $x, y \in X, M(x, y,$.$) is non-decreasing.$

Definition 2.3: [10] Let $\left(\mathrm{X}, \mathrm{M},{ }^{*}\right)$ is a fuzzy metric space.

(1) A sequence $\left\{x_{n}\right\}$ in $X$ is said to be convergent to a point $x \in X$ (denoted by $\left.\lim _{n \rightarrow \infty} x_{n}=x\right)$, if $\lim _{n \rightarrow \infty} M\left(x_{n}, x, t\right)=1$ for all $t>0$.

(2) A sequence $\left\{x_{n}\right\}$ in $X$ is called a Cauchy sequence if $\lim _{n \rightarrow \infty} M\left(x_{n+p}, x_{n}, t\right)=1$, for all $\mathrm{t}>0$ and $\mathrm{p}>0$.

(3) A fuzzy metric space in which every Cauchy sequence is convergent is said to be complete.

Lemma 2.2 :( [3], [25]) Let $\left\{y_{n}\right\}$ be a sequence in a fuzzy metric space (X, M, *). If there exists a number $k \in(0,1)$ such that $M\left(y_{n+2}, y_{n+1}, k t\right) \geq M\left(y_{n+1}, y_{n}, t\right)$ for all $\mathrm{t}>0$ and $\mathrm{n}=1,2 \ldots$ Then $\left\{\mathrm{y}_{\mathrm{n}}\right\}$ is a Cauchy sequence in $\mathrm{X}$.

Lemma 2.3: [25] If for all $x, y \in X, t>0$ and for a number $k \in(0,1), M(x, y, k t)$ $\geq M(x, y, t)$, then $x=y$.

Definition 2.4:[25] Let A and B be mappings from a fuzzy metric space (X, M, *) into itself. The mappings $A$ and $B$ are said to be compatible if $\lim _{n \rightarrow \infty} M\left(A B x_{n}\right.$, $\left.B A x_{n}, t\right)=1$, for all $t>0$, whenever $\left\{x_{n}\right\}$ is a sequence in $X$ such that $\lim _{n \rightarrow \infty} A x_{n}$ $=\lim _{\mathrm{n} \rightarrow \infty} \mathrm{Bx}_{\mathrm{n}}=\mathrm{z}$ for some $\mathrm{z} \in \mathrm{X}$.

Definition 2.5: [21] Two maps A and B are said to be weakly compatible if they commute at their coincidence point.

Definition 2.6: [26] Two mappings $f$ and $g$ of a fuzzy metric space, (X, M, *) into itself are said to be weakly commuting if $M(f g x, g f x, t) \geq M(f x, g x, t)$, for every $\mathrm{x} \in \mathrm{X}$.

Definition 2.7: [41] the mappings $f$ and $g$ of a fuzzy metric space $(X, M, *)$ into itself are R-weakly commuting provided there exists some positive real number $\mathrm{R}$ such that- $M(f g x, g f x, t) \geq M(f x, g x, t / R)$ for all $x \in X$.

(*) weak commutativity implies R-weak commutativity and the converse is true for $\mathrm{R} \leq 1$. 


\section{Main Results}

Theorem 3.1: Let $\left(\mathrm{X}, \mathrm{M},{ }^{*}\right)$ be a FM- space with $\mathrm{t} * \mathrm{t} \geq \mathrm{t} \forall \mathrm{t} \in[0,1]$. Let $\mathrm{A}, \mathrm{B}$, $\mathrm{S}$ and $\mathrm{T}$ be mappings from $\mathrm{X}$ into itself such that

(1.31) $\mathrm{A}(\mathrm{X}) \subset \mathrm{T}(\mathrm{X}), \mathrm{B}(\mathrm{X}) \subset \mathrm{S}(\mathrm{X})$,

(1.32) there exists a constant $\mathrm{k} \in(0,1)$ such that,

$M(\mathrm{Ax}, \mathrm{By}, \mathrm{kt}) \geq \mathrm{M}(\mathrm{Ty}, \mathrm{By}, \mathrm{t}) * \mathrm{M}(\mathrm{Sx}, \mathrm{Ax}, \mathrm{t}) * \mathrm{M}(\mathrm{Sx}, \mathrm{By}, \mathrm{at}) * \mathrm{M}(\mathrm{Ty}, \mathrm{Ax},(2-$

a) t) $* M(T y, S x, t)$ for all $x, y \in X, a \in(0,2)$ and $t>0$.

(1.33) One of $\mathrm{A}(\mathrm{X}), \mathrm{B}(\mathrm{X}), \mathrm{S}(\mathrm{X})$ or $\mathrm{T}(\mathrm{X})$ is a complete subspace of $\mathrm{X}$, then

(i) A and $\mathrm{S}$ have a coincidence point.

(ii) $\mathrm{B}$ and $\mathrm{T}$ have a coincidence point.

Further, if

(1.34) the pairs $\{\mathrm{A}, \mathrm{S}\}$ and $\{\mathrm{B}, \mathrm{T}\}$ are R-weakly commuting or R-weakly commutative, then

(iii) $\mathrm{A}, \mathrm{B}, \mathrm{S}$ and $\mathrm{T}$ have a unique fixed point in $\mathrm{X}$.

Proof: By (1.31), since $A(X) \subset T(X)$, for any point $x_{0} \in X$, there exists a point $x$ $\in X$ such that $\mathrm{Ax}_{0}=\mathrm{Tx}_{1}$.

Since $\mathrm{B}(\mathrm{X}) \subset \mathrm{S}(\mathrm{X})$, for this point $\mathrm{x}_{1}$ we can choose a point $\mathrm{x}_{2} \in \mathrm{X}$ such that $\mathrm{Bx}_{1}$ $=\mathrm{Sx}_{2}$ and so on.

Inductively, we can define a sequence $\left\{\mathrm{y}_{\mathrm{n}}\right\}$ in $\mathrm{X}$ such that $\mathrm{y}_{2 \mathrm{n}}=\mathrm{Ax}_{2 \mathrm{n}}=\mathrm{Tx}_{2 \mathrm{n}+1}$ and $\mathrm{y}_{2 \mathrm{n}+1}=\mathrm{Bx}_{2 \mathrm{n}+1}=\mathrm{Sx}_{2 \mathrm{n}+2}$ by (1.32), for all $\mathrm{t}>0$ and $\mathrm{a}=1-\mathrm{q}$ with $\mathrm{q} \in(0,1)$, we have;

$M\left(y_{2 n+1}, y_{2 n+2}, k t\right)=M\left(B x_{2 n+1}, A x_{2 n+2}, k t\right)=M\left(A x_{2 n+1}, B x_{2 n+2}, k t\right)$

$\geq \mathrm{M}\left(\mathrm{Tx}_{2 \mathrm{n}+1}, \mathrm{Bx}_{2 \mathrm{n}+1}, \mathrm{t}\right) * \mathrm{M}\left(\mathrm{Sx}_{2 \mathrm{n}+2}, \mathrm{Ax}_{2 \mathrm{n}+2}, \mathrm{t}\right) * \mathrm{M}\left(\mathrm{Sx}_{2 \mathrm{n}+2}, \mathrm{Bx}_{2 \mathrm{n}+1}\right.$, at $) *$

$\mathrm{M}\left(\mathrm{Tx}_{2 \mathrm{n}+1}, \mathrm{Ax}_{2 \mathrm{n}+2},(1+\mathrm{q}) \mathrm{t}\right) * \mathrm{M}\left(\mathrm{Tx}_{2 \mathrm{n}+1}, \mathrm{Sx}_{2 \mathrm{n}+2}, \mathrm{t}\right)$

$\geq M\left(y_{2 n}, y_{2 n+1}, t\right) * M\left(y_{2 n+1}, y_{2 n+2}, t\right) * M\left(y_{2 n+1}, y_{2 n+1}, a t\right) * M\left(y_{2 n}, y_{2 n+2},(1+q) t\right)$

* $\quad \mathrm{M}\left(\mathrm{y}_{2 \mathrm{n}}, \mathrm{y}_{2 \mathrm{n}+1}, \mathrm{t}\right)$

$\geq \mathrm{M}\left(\mathrm{y}_{2 \mathrm{n}}, \mathrm{y}_{2 \mathrm{n}+1}, \mathrm{t}\right) * \mathrm{M}\left(\mathrm{y}_{2 \mathrm{n}+1}, \mathrm{y}_{2 \mathrm{n}+2}, \mathrm{t}\right) * 1 * \mathrm{M}\left(\mathrm{y}_{2 \mathrm{n}}, \mathrm{y}_{2 \mathrm{n}+1}, \mathrm{t}\right) * \mathrm{M}\left(\mathrm{y}_{2 \mathrm{n}+1}, \mathrm{y}_{2 \mathrm{n}+2}, \mathrm{qt}\right) *$

$\mathrm{M}\left(\mathrm{y}_{2 \mathrm{n}}, \mathrm{y}_{2 \mathrm{n}+1}, \mathrm{t}\right)$.

$\geq M\left(y_{2 n}, y_{2 n+1}, t\right) * M\left(y_{2 n+1}, y_{2 n+2}, t\right) * M\left(y_{2 n+1}, y_{2 n+2}, q t\right)$.

Since the t-norm * is continuous and $\mathrm{M}(\mathrm{x}, \mathrm{y},$.$) is left continuous letting \mathrm{q} \rightarrow 1$.

We have;

$M\left(y_{2 n+1}, y_{2 n+2}, k t\right) \geq M\left(y_{2 n}, y_{2 n+1}, t\right) * M\left(y_{2 n+1}, y_{2 n+2}, t\right)$

Similarly, we have also

$\mathrm{M}\left(\mathrm{y}_{2 \mathrm{n}+2}, \mathrm{y}_{2 \mathrm{n}+3}, \mathrm{kt}\right) \geq \mathrm{M}\left(\mathrm{y}_{2 \mathrm{n}+1}, \mathrm{y}_{2 \mathrm{n}+2}, \mathrm{t}\right) * \mathrm{M}\left(\mathrm{y}_{2 \mathrm{n}+2}, \mathrm{y}_{2 \mathrm{n}+3}, \mathrm{t}\right)$

Thus by (1.35) and (1.66) it follows that;

$M\left(y_{n+1}, y_{n+2}, k t\right) \geq M\left(y_{n}, y_{n+1}, t\right) * M\left(y_{n+1}, y_{n+2}, t\right)$ for $n=1,2 \ldots$ and so for positive integer $\mathrm{n}, \mathrm{p}$

$M\left(y_{n+1}, y_{n+2}, k t\right) \geq M\left(y_{n}, y_{n+1}, t\right) * M\left(y_{n+1}, y_{n+2}, t / k^{p}\right)$.

Thus, since $\mathrm{M}\left(\mathrm{y}_{\mathrm{n}+1}, \mathrm{y}_{\mathrm{n}+2}, \mathrm{t} / \mathrm{k}^{\mathrm{p}}\right) \rightarrow 1$ as $\mathrm{p} \rightarrow \infty$.

We have $M\left(y_{n+1}, y_{n+2}, k t\right) \geq M\left(y_{n}, y_{n+1}, t\right)$.

By lemma (2.2), $\left\{\mathrm{y}_{\mathrm{n}}\right\}$ is a Cauchy sequence in $\mathrm{X}$.

Now suppose $\mathrm{S}(\mathrm{X})$ is complete. 
Note that the subsequences $\left\{y_{2 n+1}\right\}$ is contained in $S(X)$ and has a limit in $S(X)$. Call it $\mathrm{z}$. Let $\mathrm{u}=\mathrm{S}^{-1} \mathrm{z}$

$\mathrm{Then} \mathrm{Su}=\mathrm{z}$. we shall use the fact that the subsequences $\left(\mathrm{y}_{2 \mathrm{n}}\right\}$ also converges to $\mathrm{z}$. By (1.32), with $\mathrm{q}=1$, we have;

$\mathrm{M}\left(\mathrm{Au}, \mathrm{y}_{2 \mathrm{n}+1}, \mathrm{kt}\right)=\mathrm{M}\left(\mathrm{Au}, \mathrm{Bx}_{2 \mathrm{n}+1}, \mathrm{kt}\right)$

$\geq M\left(\mathrm{Tx}_{2 \mathrm{n}+1}, \mathrm{Bx}_{2 \mathrm{n}+1}, \mathrm{t}\right) * \mathrm{M}(\mathrm{Su}, \mathrm{Au}, \mathrm{t}) * \mathrm{M}\left(\mathrm{Su}, \mathrm{Bx}_{2 \mathrm{n}+1}, \mathrm{t}\right) * \mathrm{M}\left(\mathrm{Tx}_{2 \mathrm{n}+1}, \mathrm{Au}, \mathrm{t}\right) * \mathrm{M}$ $\left(\mathrm{Tx}_{2 \mathrm{n}+1}, \mathrm{Su}, \mathrm{t}\right)$

$=\mathrm{M}\left(\mathrm{y}_{2 \mathrm{n}}, \mathrm{y}_{2 \mathrm{n}+1}, \mathrm{t}\right) * \mathrm{M}(\mathrm{Su}, \mathrm{Au}, \mathrm{t}) * \mathrm{M}\left(\mathrm{Su}, \mathrm{y}_{2 \mathrm{n}+1}, \mathrm{t}\right) * \mathrm{M}\left(\mathrm{y}_{2 \mathrm{n}}, \mathrm{Au}, \mathrm{t}\right) * \mathrm{M}\left(\mathrm{y}_{2 \mathrm{n}}, \mathrm{Su}\right.$,

t)

This implies that as $\mathrm{n} \rightarrow \infty$

$\mathrm{M}(\mathrm{Au}, \mathrm{z}, \mathrm{kt}) \geq 1 * \mathrm{M}(\mathrm{z}, \mathrm{Au}, \mathrm{t}) * 1 * \mathrm{M}(\mathrm{z}, \mathrm{Au}, \mathrm{t}) * 1 \geq \mathrm{M}(\mathrm{z}, \mathrm{Au}, \mathrm{t})$

Therefore by lemma 2.3, we have $\mathrm{Au}=\mathrm{z}$, since $\mathrm{Su}=\mathrm{z}$ thus $\mathrm{Au}=\mathrm{z}=\mathrm{Su}$, i.e. $\mathrm{u}$ is coincidence point of $A$ and $S$. This proves (i).

Since $A(X) \subset T(X), A u=z$ implies that $z \in T(X)$. Let $v \in T^{-1} z$ then $T v=z$. It can easily verified by using similar arguments of the previous part of the proof that $\mathrm{Bv}=\mathrm{z}$.

If we assume that $\mathrm{T}(\mathrm{X})$ is complete, then argument analogous to the previous completeness argument establishes (i) and (ii). The remaining two cases pertain essentially to the previous cases. Indeed, if $B(X)$ is complete, then by (1.31), $\mathrm{z}$ $\in \mathrm{B}(X) \subset \mathrm{S}(\mathrm{X})$. Similarly if $\mathrm{A}(\mathrm{X})$ is complete, then $\mathrm{z} \in \mathrm{A}(X) \subset \mathrm{T}(\mathrm{X})$. Thus (i) and (ii) are completely established.

Since the pair $\{\mathrm{A}, \mathrm{S}\}$ is R-weakly commuting therefore by definition of R-weakly commuting we have;

$M(A S u, S A u, t) \geq M(A u, S u, t / R)$ for all $u \in X$.

$M(A z, S z, t) \geq M(z, z, t / R)$

$\mathrm{M}(\mathrm{Az}, \mathrm{Sz}, \mathrm{t}) \geq 1$

Which implies that $\mathrm{Az}=\mathrm{Sz}$.

Since the pair $\{\mathrm{B}, \mathrm{T}\}$ is R-weakly commuting therefore by definition of R-weakly commuting we have;

$M(B T v, T B v, t) \geq M(B v, T v, t / R)$ for all $v \in X$.

$\mathrm{M}(\mathrm{Bz}, \mathrm{Tz}, \mathrm{t}) \geq \mathrm{M}(\mathrm{z}, \mathrm{z}, \mathrm{t} / \mathrm{R})$

$\mathrm{M}(\mathrm{Bz}, \mathrm{Tz}, \mathrm{t}) \geq 1$

Which implies that $\mathrm{Bz}=\mathrm{Tz}$.

Now, we prove that $A z=z$. By (1.32) with $(\mathrm{a}=1)$ we have,

$\mathrm{M}\left(\mathrm{Az}, \mathrm{y}_{2 \mathrm{n}+1}, \mathrm{kt}\right)=\mathrm{M}\left(\mathrm{Az}, \mathrm{Bx}_{2 \mathrm{n}+1}, \mathrm{kt}\right)$

$\geq \mathrm{M}\left(\mathrm{Tx}_{2 \mathrm{n}+1}, \mathrm{Bx}_{2 \mathrm{n}+1}, \mathrm{t}\right) * \mathrm{M}(\mathrm{Sz}, \mathrm{Az}, \mathrm{t}) * \mathrm{M}\left(\mathrm{Sz}, \mathrm{Bx}_{2 \mathrm{n}+1}, \mathrm{t}\right) * \mathrm{M}\left(\mathrm{Tx}_{2 \mathrm{n}+1}, \mathrm{Az}, \mathrm{t}\right) *$

$\mathrm{M}\left(\mathrm{Tx}_{2 \mathrm{n}+1}, \mathrm{Sz}, \mathrm{t}\right)$

Taking the limit as $\mathrm{n} \rightarrow \infty$, we have;

$\mathrm{M}(\mathrm{Az}, \mathrm{z}, \mathrm{t}) \geq 1 * 1 * \mathrm{M}(\mathrm{Az}, \mathrm{z}, \mathrm{t}) * \mathrm{M}(\mathrm{z}, \mathrm{Az}, \mathrm{t}) * \mathrm{M}(\mathrm{z}, \mathrm{Az}, \mathrm{t}) \geq \mathrm{M}(\mathrm{Az}, \mathrm{z}, \mathrm{t})$

Therefore by lemma 2.3, we have $\mathrm{Az}=\mathrm{z}$, since $\mathrm{Az}=\mathrm{Sz}$ therefore $\mathrm{Az}=\mathrm{Sz}=\mathrm{z}$.

Similarly, we have $\mathrm{Bz}=\mathrm{Tz}=\mathrm{z}$.

This means that $\mathrm{z}$ is a common fixed point of $\mathrm{A}, \mathrm{B}, \mathrm{S}$ and $\mathrm{T}$.

Uniqueness: Let $\mathrm{w} \neq \mathrm{z}$ be another common fixed point of $\mathrm{A}, \mathrm{B}, \mathrm{S}$ and $\mathrm{T}$.

Then by (1.32) with $\mathrm{a}=1$, we have 
$M(\mathrm{z}, \mathrm{w}, \mathrm{kt})=\mathrm{M}(\mathrm{Az}, \mathrm{Bw}, \mathrm{kt})$

$\geq \mathrm{M}(\mathrm{Tw}, \mathrm{Bw}, \mathrm{t}) * \mathrm{M}(\mathrm{Sz}, \mathrm{Az}, \mathrm{t}) * \mathrm{M}(\mathrm{Sz}, \mathrm{Bw}, \mathrm{t}) * \mathrm{M}(\mathrm{Tw}, \mathrm{Az}, \mathrm{t})$

$* \mathrm{M}(\mathrm{Tw}, \mathrm{Sz}, \mathrm{t})$

$$
\begin{aligned}
& \geq 1 * 1 * M(\mathrm{z}, \mathrm{w}, \mathrm{t}) * \mathrm{M}(\mathrm{w}, \mathrm{z}, \mathrm{t}) * \mathrm{M}(\mathrm{w}, \mathrm{z}, \mathrm{t}) * \mathrm{M}(\mathrm{w}, \mathrm{z}, \mathrm{t}) \\
& \geq \mathrm{M}(\mathrm{z}, \mathrm{w}, \mathrm{t}) .
\end{aligned}
$$

Therefore by lemma 2.3 , we have $\mathrm{z}=\mathrm{w}$.

This completes the proof.

If we take $S=T$. Then we have the following theorem.

Theorem 3.2: Let $\left(\mathrm{X}, \mathrm{M},{ }^{*}\right)$ be a FM- space with $\mathrm{t} * \mathrm{t} \geq \mathrm{t} \forall \mathrm{t} \in[0,1]$. Let $\mathrm{A}, \mathrm{B}$, $\mathrm{S}$ and $\mathrm{T}$ be mappings from $\mathrm{X}$ into itself such that

(2.31) $\mathrm{A}(\mathrm{X}) \cup \mathrm{B}(\mathrm{X}) \subset \mathrm{T}(\mathrm{X})$.

(2.32) there exists a constant $\mathrm{k} \in(0,1)$ such that

$\mathrm{M}(\mathrm{Ax}, \mathrm{By}, \mathrm{kt}) \geq \mathrm{M}(\mathrm{Ty}, \mathrm{By}, \mathrm{t}) * \mathrm{M}(\mathrm{Tx}, \mathrm{Ax}, \mathrm{t}) * \mathrm{M}(\mathrm{Tx}, \mathrm{By}, \mathrm{at}) * \mathrm{M}(\mathrm{Ty}, \mathrm{Ax},(2-\mathrm{a}) \mathrm{t})$

$* \mathrm{M}(\mathrm{Ty}, \mathrm{Tx}, \mathrm{t})$ for all $\mathrm{x}, \mathrm{y} \in \mathrm{X}, \mathrm{a} \in(0,2)$ and $\mathrm{t}>0$.

(2.33) one of $\mathrm{A}(\mathrm{X}), \mathrm{B}(\mathrm{X})$ or $\mathrm{T}(\mathrm{X})$ is a complete subspace of $\mathrm{X}$,

then $\mathrm{A}, \mathrm{B}$ and $\mathrm{T}$ have a coincidence point.

Further, if

(2.34) the pairs $\{\mathrm{A}, \mathrm{T}\}$ and $\{\mathrm{B}, \mathrm{T}\}$ are $\mathrm{R}$-weakly commuting then $\mathrm{A}, \mathrm{B}$, and $\mathrm{T}$ have a unique common fixed point in $\mathrm{X}$.

Proof: The proof is similar to the proof of theorem 3.1.

We improve Theorem 3.1 for sequence of mappings in the following manner.

Theorem 3.3: Let $(X, M, *)$ be a FM- Space with $t * t \geq t$ for all $t \in[0,1]$. Let $S$, $\mathrm{T}, \mathrm{A}_{i}: \mathrm{X} \rightarrow \mathrm{X}, \mathrm{i}=0,1,2 \ldots$ such that

(3.31) $\mathrm{A}_{0}(\mathrm{X}) \subset \mathrm{T}(\mathrm{X}), \mathrm{Ai}(\mathrm{X}) \subset \mathrm{S}(\mathrm{X}), \mathrm{i} \in \mathrm{N}$

(3.32) there exists a constant $\mathrm{k} \in(0,1)$ such that

$M\left(A_{0} x, A_{i} y, k t\right) \geq M\left(T y, A_{i} y, t\right) * M\left(S x, A_{0} x, t\right) * M\left(S x, A_{i} y, a t\right) * M(T y$, $\left.A_{0} x,(2-a) t\right) * M(T y, S x, t)$ for all $x, y \in X, a \in(0,2)$ and $t>0$.

(3.33) the pairs $\left\{A_{0}, S\right\}$, and $\{A i, T\}(i \in N)$ are R-weakly commuting.

If one of $\mathrm{S}(\mathrm{X}), \mathrm{T}(\mathrm{X})$ or $\mathrm{A}_{0}(\mathrm{X})$ is a complete subspace of $\mathrm{X}$. or alternatively, $\mathrm{Ai}, \mathrm{i}$ $\in \mathrm{N}$ are complete subspaces of $\mathrm{X}$, then $\mathrm{S}, \mathrm{T}$ and $\mathrm{Ai}, \mathrm{i}=0,1,2 \ldots$ have a unique common fixed point.

Now, we extend Theorem 3.1 in the following way.

Theorem 3.4: Let $(X, M *)$ be a FM- Space with $t * t \geq t$ for all $t \in[0,1]$. Let $A$, $\mathrm{B}, \mathrm{S}, \mathrm{T}$ and $\mathrm{P}$ be mappings from $\mathrm{X}$ into itself such that

(4.31) $\mathrm{P}(\mathrm{X}) \subset \mathrm{AB}(\mathrm{X}), \mathrm{P}(\mathrm{X}) \subset \mathrm{ST}(\mathrm{X})$

(4.32) there exists a constant $\mathrm{k} \in(0,1)$ such that

$\mathrm{M}(\mathrm{Px}, \mathrm{Py}, \mathrm{kt}) \geq \mathrm{M}(\mathrm{ABy}, \mathrm{Py}, \mathrm{t}) * \mathrm{M}(\mathrm{STx}, \mathrm{Px}, \mathrm{t}) * \mathrm{M}(\mathrm{ST}, \mathrm{Py}, \mathrm{at}) * \mathrm{M}(\mathrm{ABy}, \mathrm{Px}$, $(2-a) t) * M(A B y, S T x, t)$ for all $x, y \in X, a \in(0,2)$ and $t>0$.

(4.33) if one of $\mathrm{P}(\mathrm{X}), \mathrm{AB}(\mathrm{X})$ or $\mathrm{ST}(\mathrm{X})$ is a complete subspace of $\mathrm{X}$, then 
(i) $\mathrm{P}$ and $\mathrm{AB}$ have a coincidence point.

(ii) $\mathrm{P}$ and $\mathrm{ST}$ have a coincidence point.

Further if,

(4.34) $\mathrm{PB}=\mathrm{BP}, \mathrm{AB}=\mathrm{BA}, \mathrm{PT}=\mathrm{TP}$ and $\mathrm{ST}=\mathrm{TS}$

(4.35) the pairs $\{\mathrm{P}, \mathrm{AB}\}$ and $\{\mathrm{P}, \mathrm{ST}\}$ are $\mathrm{R}$-weakly commuting, then

(iii) $\mathrm{A}, \mathrm{B}, \mathrm{S}, \mathrm{T}$ and $\mathrm{P}$ have a unique common fixed point in $\mathrm{X}$.

Proof: By (1.31), since $\mathrm{P}(\mathrm{X}) \subset \mathrm{AB}(\mathrm{X})$, for any point $\mathrm{x}_{0} \in \mathrm{X}$, there exists a point $\mathrm{x}_{1} \in \mathrm{X}$ such that $\mathrm{Px}_{0}=\mathrm{ABx}_{1}$.

Since $\mathrm{P}(\mathrm{X}) \subset \mathrm{ST}(\mathrm{X})$, for this point $\mathrm{x}_{1}$ we can choose a point $\mathrm{x}_{2} \in \mathrm{X}$ such that $\mathrm{Px}_{1}$ $=\mathrm{Sx}_{2}$ and so on. Inductively we can define a sequence $\left\{\mathrm{y}_{\mathrm{n}}\right\}$ in $\mathrm{X}$ such that

$\mathrm{y}_{2 \mathrm{n}}=\operatorname{Px}_{2 \mathrm{n}}=\mathrm{ABx}_{2 \mathrm{n}+1}$ and $\mathrm{y}_{2 \mathrm{n}+1}=\operatorname{Px}_{2 \mathrm{n}+1}=\operatorname{STx}_{2 \mathrm{n}+2}$ for $\mathrm{n}=0,1,2 \ldots$

Then as proved in Theorem 3.1, we can prove that $\left\{y_{n}\right\}$ is a Cauchy sequence in $X$. Now suppose that $S T(X)$ is complete. Note that the subsequence $\left\{y_{2 n+1}\right\}$ is contained in $\mathrm{ST}(\mathrm{X})$ and has a limit in $\mathrm{ST}(\mathrm{X})$. Call it $\mathrm{z}$. Let $\mathrm{u}=\mathrm{ST}^{-1} \mathrm{z}$

Then $S T u=z$. We shall use the fact that the subsequence $\left\{y_{2 n}\right\}$ also converges to $\mathrm{z}$.

By (4.32) with $\mathrm{a}=1$, we have,

$\mathrm{M}\left(\mathrm{Pu}, \mathrm{y}_{2 \mathrm{n}+1}, \mathrm{kt}\right)=\mathrm{M}\left(\mathrm{Pu}, \mathrm{Px}_{2 \mathrm{n}+1}, \mathrm{kt}\right)$

$\geq \mathrm{M}\left(\mathrm{ABx}_{2 \mathrm{n}+1}, \mathrm{Px}_{2 \mathrm{n}+1}, \mathrm{t}\right) * \mathrm{M}(\mathrm{STu}, \mathrm{Pu}, \mathrm{t}) * \mathrm{M}\left(\mathrm{STu}, \mathrm{Px}_{2 \mathrm{n}+1}, \mathrm{t}\right) *$

$\mathrm{M}\left(\mathrm{ABx}_{2 \mathrm{n}+1}, \mathrm{Pu}, \mathrm{t}\right) * \mathrm{M}\left(\mathrm{ABx}_{2 \mathrm{n}+1}, \mathrm{STu}, \mathrm{t}\right)$

$=\mathrm{M}\left(\mathrm{y}_{2 \mathrm{n}}, \mathrm{y}_{2 \mathrm{n}+1}, \mathrm{t}\right) * \mathrm{M}(\mathrm{STu}, \mathrm{Pu}, \mathrm{t}) * \mathrm{M}\left(\mathrm{STu}, \mathrm{y}_{2 \mathrm{n}+1}, \mathrm{t}\right) * \mathrm{M}\left(\mathrm{y}_{2 \mathrm{n}}, \mathrm{Pu}, \mathrm{t}\right)$

Taking the limit $\mathrm{n} \rightarrow \infty$, we have;

$\mathrm{M}(\mathrm{Pu}, \mathrm{z}, \mathrm{kt}) \geq 1 * \mathrm{M}(\mathrm{z}, \mathrm{Pu}, \mathrm{t}) * 1 * \mathrm{M}(\mathrm{z}, \mathrm{u}, \mathrm{t}) * 1$

$\geq \mathrm{M}(\mathrm{Pu}, \mathrm{z}, \mathrm{t})$,

Therefore by lemma 2.3, we have $\mathrm{Pu}=\mathrm{z}$. Since $\mathrm{STu}=\mathrm{z}$.

Thus $\mathrm{Pu}=\mathrm{z}=\mathrm{STu}$.

I.e. $\mathrm{u}$ is coincidence point of $\mathrm{P}$ and $\mathrm{ST}$. This proves (i)

Since $\mathrm{P}(\mathrm{X}) \subset \mathrm{AB}(\mathrm{X}), \mathrm{Pu}=\mathrm{z}$ implies that $\mathrm{z} \in \mathrm{AB}(\mathrm{X})$, Let $\mathrm{v} \in(\mathrm{AB})^{-1} \mathrm{z}$ then $\mathrm{ABv}$ $=\mathrm{z}$. It can easily verified by using similar arguments of the previous part of the proof that $\mathrm{Pv}=\mathrm{z}$. If we assume that $\mathrm{AB}(\mathrm{X})$ is complete, then argument analogous to the previous completeness argument establishes (i) and (ii).

The remaining one case pertains essentially to the previous cases. Indeed if, $\mathrm{P}(\mathrm{X})$ is complete then by (4.31), $\mathrm{z} \in \mathrm{P}(\mathrm{X}) \subset \mathrm{ST}(\mathrm{X})$ or $\mathrm{z} \in \mathrm{P}(\mathrm{X}) \subset \mathrm{AB}(\mathrm{X})$. Thus (i) and (ii) are completely established.

Since the pair $\{\mathrm{P}, \mathrm{ST}\}$ is R-weakly commuting, therefore by definition of Rweakly commuting, we have

$M(P S T u, S T P u, t) \geq M(P u, S T u, t / R)$ for all $u \in X$.

$\mathrm{M}(\mathrm{Pz}, \mathrm{Stz}, \mathrm{t}) \geq \mathrm{M}(\mathrm{z}, \mathrm{z}, \mathrm{t} / \mathrm{R})$ i.e. $\mathrm{M}(\mathrm{Pz}, \mathrm{STz}, \mathrm{t})=1$.

Which implies that $\mathrm{Pz}=\mathrm{STz}$.

Similarly, the pair $\{\mathrm{P}, \mathrm{AB}\}$ is $\mathrm{R}$-weakly commuting, therefore by definition of $\mathrm{R}$ weakly commuting, we have,

$M(P A B v, A B P v, t) \geq M(P v, A B v, t / R)$ for all $v \in X$.

$\mathrm{M}(\mathrm{Pz}, \mathrm{ABz}, \mathrm{t}) \geq \mathrm{M}(\mathrm{z}, \mathrm{z}, \mathrm{t} / \mathrm{R})$ i.e $\mathrm{M}(\mathrm{Pz}, \mathrm{ABz}, \mathrm{t})=1$ 
Which implies that $\mathrm{Pz}=\mathrm{ABz}$.

Now, we prove that $\mathrm{Pz}=\mathrm{z}$. By (4.32) with $\mathrm{a}=1$ we have,

$\mathrm{M}\left(\mathrm{Pz}, \mathrm{y}_{2 \mathrm{n}+1}, \mathrm{kt}\right)=\mathrm{M}\left(\mathrm{Pz}, \mathrm{Px}_{2 \mathrm{n}+1}, \mathrm{kt}\right)$

$\geq \mathrm{M}\left(\mathrm{ABx}_{2 \mathrm{n}+1}, \mathrm{Px}_{2 \mathrm{n}+1}, \mathrm{t}\right) * \mathrm{M}(\mathrm{STz}, \mathrm{Pz}, \mathrm{t}) * \mathrm{M}\left(\mathrm{STz}, \mathrm{Px}_{2 \mathrm{n}+1}, \mathrm{t}\right) *$

$\mathrm{M}\left(\mathrm{Bx}_{2 \mathrm{n}+1}, \mathrm{Pz}, \mathrm{t}\right) * \mathrm{M}\left(\mathrm{ABx}_{2 \mathrm{n}+1}, \mathrm{STz}, \mathrm{t}\right)$

$\geq \mathrm{M}\left(\mathrm{y}_{2 \mathrm{n}}, \mathrm{y}_{2 \mathrm{n}+1}, \mathrm{t}\right) * \mathrm{M}(\mathrm{Pz}, \mathrm{Pz}, \mathrm{t}) * \mathrm{M}\left(\mathrm{STz}, \mathrm{y}_{2 \mathrm{n}+1}, \mathrm{t}\right) * \mathrm{M}\left(\mathrm{y}_{2 \mathrm{n}}, \mathrm{Pz}, \mathrm{t}\right) * \mathrm{M}\left(\mathrm{y}_{2 \mathrm{n}}\right.$, $\mathrm{STz}, \mathrm{t})$.

Taking the limit $\mathrm{n} \rightarrow \infty$, we have,

$\mathrm{M}(\mathrm{Pz}, \mathrm{z}, \mathrm{kt}) \geq 1 * 1 * \mathrm{M}(\mathrm{Pz}, \mathrm{z}, \mathrm{t}) * \mathrm{M}(\mathrm{z}, \mathrm{Pz}, \mathrm{t}) * \mathrm{M}(\mathrm{z}, \mathrm{Pz}, \mathrm{t}) \geq \mathrm{M}(\mathrm{Pz}, \mathrm{z}, \mathrm{t})$

Which implies that $\mathrm{Pz}=\mathrm{z}$.

Now, we show that $\mathrm{Bz}=\mathrm{z}$. Infact, by (4.32) with $\mathrm{a}=1$ and (4.34), we have;

$\mathrm{M}(\mathrm{z}, \mathrm{Bz}, \mathrm{kt})=\mathrm{M}(\mathrm{Pz}, \mathrm{BPz}, \mathrm{kt})=\mathrm{M}(\mathrm{Pz}, \mathrm{PBz}, \mathrm{kt})$

$\geq \mathrm{M}(\mathrm{AB}(\mathrm{Bz}), \mathrm{PBz}, \mathrm{t}) * \mathrm{M}(\mathrm{STz}, \mathrm{Pz}, \mathrm{t}) * \mathrm{M}(\mathrm{STz}, \mathrm{PBz}, \mathrm{t}) *$

$\mathrm{M}(\mathrm{AB}(\mathrm{Bz}), \mathrm{Pz}, \mathrm{t}) * \mathrm{M}(\mathrm{AB}(\mathrm{Bz}), \mathrm{STz}, \mathrm{t})$

$=1 * 1 * \mathrm{M}(\mathrm{z}, \mathrm{Bz}, \mathrm{t}) * \mathrm{M}(\mathrm{Bz}, \mathrm{z}, \mathrm{t}) * \mathrm{M}(\mathrm{Bz}, \mathrm{z}, \mathrm{t})$

$\geq \mathrm{M}(\mathrm{z}, \mathrm{Bz}, \mathrm{t})$

Which implies that $\mathrm{Bz}=\mathrm{z}$. since $\mathrm{ABz}=\mathrm{z}$ therefore $\mathrm{Az}=\mathrm{z}$.

Finally we show that $\mathrm{Tz}=\mathrm{z}$. indeed, by (4.32) with $\mathrm{a}=1$ and (4.34),

$\mathrm{M}(\mathrm{Tz}, \mathrm{z}, \mathrm{kt})=\mathrm{M}(\mathrm{TPz}, \mathrm{Pz}, \mathrm{kt})=\mathrm{M}(\mathrm{PTz}, \mathrm{Pz}, \mathrm{kt})$

$\geq \mathrm{M}(\mathrm{ABz}, \mathrm{Pz}, \mathrm{t}) * \mathrm{M}(\mathrm{ST}(\mathrm{Tz}), \mathrm{PTz}, \mathrm{t}) * \mathrm{M}(\mathrm{ST}(\mathrm{Tz}), \mathrm{Pz}, \mathrm{t}) *$

$\mathrm{M}(\mathrm{ABz}, \mathrm{P}(\mathrm{Tz}), \mathrm{t}) * \mathrm{M}(\mathrm{ABz}, \mathrm{ST}(\mathrm{Tz}), \mathrm{t})$

$=1 * 1 * \mathrm{M}(\mathrm{Tz}, \mathrm{z}, \mathrm{t}) * \mathrm{M}(\mathrm{z}, \mathrm{Tz}, \mathrm{t}) * \mathrm{M}(\mathrm{z}, \mathrm{Tz}, \mathrm{t})$

$\geq \mathrm{M}(\mathrm{Tz}, \mathrm{z}, \mathrm{t})$.

Which implies that $\mathrm{Tz}=\mathrm{z}$. Since $\mathrm{STz}=\mathrm{z}$, we have $\mathrm{z}=\mathrm{STz}=\mathrm{Sz}$. Therefore, by combining the above, results, we have $\mathrm{Az}=\mathrm{Bz}=\mathrm{Sz}=\mathrm{Tz}=\mathrm{Pz}=\mathrm{z}$, that is $\mathrm{z}$ is the common fixed point of $\mathrm{A}, \mathrm{B}, \mathrm{S}, \mathrm{T}$ and $\mathrm{P}$.

The uniqueness of the common fixed point of $\mathrm{A}, \mathrm{B}, \mathrm{S}, \mathrm{T}$ and $\mathrm{P}$ follows easily from (4.32).

This completes the proof.

If we put $\mathrm{B}=\mathrm{T}=\mathrm{I}$ (the identity mapping on $\mathrm{X}$ ) in theorem 3.4 , we have the following result.

Corollary 3.1: Let $(\mathrm{X}, \mathrm{M}, *)$ be a FM- Space with $\mathrm{t} * \mathrm{t} \geq \mathrm{t}$ for all $\mathrm{t} \in[0,1]$.Let $\mathrm{A}$, $\mathrm{S}$ and $\mathrm{P}$ be mappings from $\mathrm{X}$ into itself such that.

(1.31) $\mathrm{P}(\mathrm{X}) \subset \mathrm{A}(\mathrm{X}), \mathrm{P}(\mathrm{X}) \subset \mathrm{S}(\mathrm{X})$,

(1.32) there exists a constant $\mathrm{k} \in(0,1)$ such that

$M(P x, P y, k t) \geq M(A y, P y, t) * M(S x, P y, a t) * M(A y, P x,(2-a) t) * M(A y, S x$, t)

for all $\mathrm{x}, \mathrm{y} \in \mathrm{X}, \mathrm{a} \in(0,2)$ and $\mathrm{t}>0$.

(1.33) if one of $\mathrm{P}(\mathrm{X}), \mathrm{A}(\mathrm{X})$ or $\mathrm{S}(\mathrm{X})$ is a complete subspace of $\mathrm{X}$, then.

(i) $\mathrm{P}$ and $\mathrm{A}$ have a coincidence point.

(ii) $\mathrm{P}$ and $\mathrm{S}$ have a coincidence point.

Further, if

(1.34) the pairs $\{\mathrm{P}, \mathrm{A}\}$ and $\{\mathrm{P}, \mathrm{S}\}$ are $\mathrm{R}$-weakly commuting then, 
(iii) $\mathrm{A}, \mathrm{S}$ and $\mathrm{P}$ have a unique common fixed point in $\mathrm{X}$.

If we put $\mathrm{A}=\mathrm{B}=\mathrm{S}=\mathrm{T}=\mathrm{I}$ (the identity mapping on $\mathrm{X}$ ) in theorem 3.4 , we have the following.

Corollary 3.2: Let $(X, M, *)$ be a FM- Space with $t * t \geq t$, for all $t \in[0,1]$. Let $\mathrm{P}$ be mappings from $\mathrm{X}$ into itself such that.

(2.31) there exists a constant $\mathrm{k} \in(0,1)$ such that, $M(P x, P y, k t) \geq M(y, P y, t) * M(x, P x, t) * M(x, P y, a t) * M(y, P x,(2-a) t) * M(y$, $\mathrm{x}, \mathrm{t}$ )

for all $\mathrm{x}, \mathrm{y} \in \mathrm{X}, \mathrm{a} \in(0,2)$ and $\mathrm{t}>0$.

If $\mathrm{P}(\mathrm{X})$ is a complete subspace of $\mathrm{X}$ then $\mathrm{P}$ has q unique common fixed point in $\mathrm{X}$. By using theorem 3.4, we have the following

Theorem 3.5: Let $(X, M, *)$ be a FM- Space with $t * t \geq t$ for all $t \in[0,1]$. Let $A$, $\mathrm{B}, \mathrm{S}$, and $\mathrm{T}$ and $\left\{\mathrm{P}_{\mathrm{i}}\right\}_{i \in \Lambda}$ is be mappings from $\mathrm{X}$ into itself.

(5.31) $\mathrm{Y}_{i \in \Lambda} \mathrm{Pi}(\mathrm{x}) \subset \mathrm{AB}(\mathrm{X}), \mathrm{Y}_{i \in \Lambda} \mathrm{Pi}(\mathrm{X}) \subset \mathrm{ST}(\mathrm{X})$, where $\Lambda$ is an index set,

(5.32) there exists a constant $k \in(0,1)$ such that

$\mathrm{M}\left(\mathrm{P}_{i} \mathrm{x}, \mathrm{P}_{i} \mathrm{y}, \mathrm{kt}\right) \geq \mathrm{M}\left(\mathrm{ABy}, \mathrm{P}_{i} \mathrm{y}, \mathrm{t}\right) * \mathrm{M}\left(\mathrm{STx}, \mathrm{P}_{i} \mathrm{x}, \mathrm{t}\right) * \mathrm{M}\left(\mathrm{STx}, \mathrm{P}_{i} \mathrm{y}\right.$, at $) * \mathrm{M}$ $\left(\mathrm{ABy}, \mathrm{P}_{i} \mathrm{x},(2-\mathrm{a}) \mathrm{t}\right) * \mathrm{M}(\mathrm{By}, \mathrm{STx}, \mathrm{t}) \quad$ for all $\mathrm{x}, \mathrm{y} \in \mathrm{X}, \mathrm{a} \in(0,2), \mathrm{i} \in \Lambda$ and $\mathrm{t}>0$.

(5.33) if one of $\mathrm{AB}(\mathrm{X})$ or $\mathrm{ST}(\mathrm{X})$ or $\mathrm{P}_{i}(\mathrm{X})(\mathrm{i} \in \Lambda)$ is a complete subspace of $\mathrm{X}$ then,

(i) For all $\mathrm{i} \in \Lambda, \mathrm{P}_{i}$ and $\mathrm{AB}$ have a coincidence point,

(ii) For all $\mathrm{i} \in \Lambda, \mathrm{P}_{i}$ and $\mathrm{ST}$ have a coincidence point. Further, if

(5.34) for all $\mathrm{i} \in \Lambda, \mathrm{P}_{i} \mathrm{~B}=\mathrm{BP}_{i}, \mathrm{AB}=\mathrm{BA}, \mathrm{P}_{i} \mathrm{~T}=\mathrm{TP}_{i}$ and $\mathrm{ST}=\mathrm{TS}$.

(5.35) for all $\mathrm{i} \in \Lambda$ the pairs $\left\{\mathrm{P}_{i}, \mathrm{AB}\right\}$ and $\left\{\mathrm{P}_{i}, \mathrm{ST}\right\}$ are R- weakly commuting, then

(iii) $\mathrm{A}, \mathrm{B}, \mathrm{S}, \mathrm{T}$ and $\{\mathrm{Pi}\}_{i \in \Lambda}$ have a unique common fixed point in $\mathrm{X}$.

Following is an extension of Theorem 3.4.

Theorem 3.6: Let $(X, M, *)$ be a FM- Space with $t * t \geq t$ for all $t \in[0,1]$. Let $A$, $\mathrm{B}, \mathrm{S}, \mathrm{T}, \mathrm{P}$ and $\mathrm{Q}$ be mappings from $\mathrm{X}$ into itself such that

(6.31) $\mathrm{P}(\mathrm{X}) \subset \mathrm{AB}(\mathrm{X}), \mathrm{Q}(\mathrm{X}) \subset \mathrm{ST}(\mathrm{X})$,

(6.32) there exists a constant $\mathrm{k} \in(0,1)$ such that

$\mathrm{M}(\mathrm{Px}, \mathrm{Qy}, \mathrm{kt}) \geq \mathrm{M}(\mathrm{By}, \mathrm{Qy}, \mathrm{t}) * \mathrm{M}(\mathrm{STx}, \mathrm{Px}, \mathrm{t}) * \mathrm{M}(\mathrm{STx}, \mathrm{Qy}, \mathrm{at}) * \mathrm{M}(\mathrm{ABy}, \mathrm{Px}$, $(2-a) t) * M(A B y, S T x, t)$ for all $x, y \in X, a \in(0,2)$ and $t>0$.

(6.33) if one of $\mathrm{P}(\mathrm{X}), \mathrm{Q}(\mathrm{X}), \mathrm{AB}(\mathrm{X})$ or $\mathrm{ST}(\mathrm{X})$ is a complete subspace of $\mathrm{X}$, then

(i) $\mathrm{P}$ and $\mathrm{ST}$ have a coincidence point,

(ii) $\mathrm{Q}$ and $\mathrm{AB}$ have a coincidence point,

Further, if 
(6.34) $\mathrm{AB}=\mathrm{BA}, \mathrm{QB}=\mathrm{BQ}, \mathrm{PT}=\mathrm{TB}$ and $\mathrm{ST}=\mathrm{TS}$,

(6.35) the pairs $\{\mathrm{Q}, \mathrm{AB}\}$ and $\{\mathrm{P}, \mathrm{ST}\}$ are R-weakly commuting, then

(iii) A, B, S, T, P and $\mathrm{Q}$ have a unique common fixed point in $\mathrm{X}$.

Proof: $\mathrm{By}$ (6.31) Since $\mathrm{P}(\mathrm{X}) \subset \mathrm{AB}(\mathrm{X})$, for a point $\mathrm{x}_{0} \in X$, there exists a point $\mathrm{x}_{1}$ $\in X$ such that $\mathrm{Px}_{0}=\mathrm{ABx}_{1}$.

Since $\mathrm{Q}(\mathrm{X}) \subset \mathrm{ST}(\mathrm{X})$, for this point $\mathrm{x}_{1}$ we can choose a point $\mathrm{x}_{2} \in \mathrm{X}$ such that $\mathrm{Qx}_{1}=\mathrm{STx}_{2}$ and So on. Inductively we can define a sequence $\left\{\mathrm{y}_{\mathrm{n}}\right\}$ is $\mathrm{X}$ such that $\mathrm{Y}_{2 \mathrm{n}}=\mathrm{Px}_{2 \mathrm{n}}=\mathrm{ABx}_{2 \mathrm{n}+1}=\mathrm{Qx}_{2 \mathrm{n}+1}=\mathrm{STx}_{2 \mathrm{n}+2}$ for $\mathrm{n}=0,1,2 \ldots$ As proved in theorem 1, we can prove that $\left\{y_{n}\right\}$ is a Cauchy sequence in $X$.

Now, Suppose ST(X) is complete. Note that the subsequences $\left\{y_{2 n+1}\right\}$ is contained in $\mathrm{ST}(\mathrm{X})$ and has a limit in $\mathrm{ST}(\mathrm{X})$. Call it $\mathrm{z}$. Let $\mathrm{u} \in \mathrm{ST}^{-1} \mathrm{z}$ then $\mathrm{STu}=\mathrm{z}$ we shall use the fact that the subsequence $\left\{\mathrm{y}_{2 \mathrm{n}}\right\}$ also converges to $\mathrm{z}$.

By (6.32) with $\mathrm{a}=1$, we have;

$\mathrm{M}\left(\mathrm{Pu}, \mathrm{y}_{2 \mathrm{n}+1}, \mathrm{kt}\right)=\mathrm{M}\left(\mathrm{Pu}, \mathrm{Qx}_{2 \mathrm{n}+1}, \mathrm{kt}\right)$

$\geq \mathrm{M}\left(\mathrm{y}_{2 \mathrm{n}}, \mathrm{y}_{2 \mathrm{n}+1}, \mathrm{t}\right) * \mathrm{M}(\mathrm{Tu}, \mathrm{Pu}, \mathrm{t}) * \mathrm{M}\left(\mathrm{STu}, \mathrm{y}_{2 \mathrm{n}+1}, \mathrm{t}\right) * \mathrm{M}\left(\mathrm{y}_{2 \mathrm{n}+1}, \mathrm{Pu}, \mathrm{t}\right) *$

$\mathrm{M}\left(\mathrm{y}_{2 \mathrm{n}+1}, \mathrm{STu}, \mathrm{t}\right)$

Which implies that as $\mathrm{n} \rightarrow \infty, \mathrm{M}(\mathrm{Pu}, \mathrm{z}, \mathrm{kt}) \geq \mathrm{M}(\mathrm{Pu}, \mathrm{z}, \mathrm{t})$.

Therefore by lemma 2.3, we have $\mathrm{Pu}=\mathrm{z}$.

Since $\mathrm{STu}=\mathrm{z}$ thus $\mathrm{Pu}=\mathrm{z}=\mathrm{STu}$

I.e. $\mathrm{u}$ is a coincidence point of $\mathrm{P}$ and $\mathrm{ST}$. This proves (i).

Since $\mathrm{P}(\mathrm{X}) \subset \mathrm{AB}(\mathrm{X}), \mathrm{Pu}=\mathrm{z}$ implies that $\mathrm{z} \in \mathrm{AB}(\mathrm{X})$.

Let $\mathrm{v} \in(\mathrm{AB})^{-1} \mathrm{z}$. Then $\mathrm{Bv}=\mathrm{z}$

By (6.32), with $\mathrm{a}=1$ we have,

$\mathrm{M}\left(\mathrm{y}_{2 \mathrm{n}+1}, \mathrm{Qv}, \mathrm{kt}\right)=\mathrm{M}\left(\mathrm{Px}_{2 \mathrm{n}+1}, \mathrm{Qv}, \mathrm{kt}\right)$

$\geq \mathrm{M}(\mathrm{ABv}, \mathrm{Qv}, \mathrm{t}) * \mathrm{M}\left(\mathrm{y}_{2 \mathrm{n}+1}, \mathrm{y}_{2 \mathrm{n}+2}, \mathrm{t}\right) * \mathrm{M}\left(\mathrm{y}_{2 \mathrm{n}+1}, \mathrm{Qv}, \mathrm{t}\right) * \mathrm{M}\left(\mathrm{ABv}, \mathrm{y}_{2 \mathrm{n}+2}, \mathrm{t}\right) *$ $M\left(A B v, y_{2 n+1}, t\right)$

Which implies that as $\mathrm{n} \rightarrow \infty, \mathrm{M}(\mathrm{z}, \mathrm{Qv}, \mathrm{kt}) \geq \mathrm{M}(\mathrm{z}, \mathrm{Qv}, \mathrm{t})$.

Therefore by lemma 2.3, we have $\mathrm{Qv}=\mathrm{z}$.

Since $\mathrm{ABv}=\mathrm{z}$ thus $\mathrm{Qv}=\mathrm{z}=\mathrm{ABv}$

I.e. $\mathrm{v}$ is coincidence point of $\mathrm{Q}$ and $\mathrm{AB}$. This proves (ii).

The remaining two cases pertain essentially to the previous. Indeed if $\mathrm{P}(\mathrm{X})$ or $\mathrm{Q}(\mathrm{X})$ is complete, then by (6.31) $\mathrm{z} \in \mathrm{P}(\mathrm{X}) \subset \mathrm{AB}(\mathrm{X})$ or $\mathrm{z} \in \mathrm{Q}(\mathrm{X}) \subset \mathrm{ST}(\mathrm{X})$.

Thus (i) and (ii) are completely established.

Since the pair $\{\mathrm{P}, \mathrm{ST}\}$ is R-weakly commuting, therefore by definition of Rweakly commuting, we have,

$M(P S T u, S T P u, t) \geq M(P u, S T u, t / R)$ for all $u \in X$,

I.e. $M(P z, S T z, t) \geq M(z, z, t / R)$

$\mathrm{M}(\mathrm{Pz}, \mathrm{STz}, \mathrm{t}) \geq 1$

Which implies that $\mathrm{Pz}=\mathrm{STz}$.

Since, the pair $\{\mathrm{Q}, \mathrm{AB}\}$ is $\mathrm{R}$-weakly commuting therefore by definition of $\mathrm{R}$ weakly commuting, we have,

$M(Q A B v, A B Q v, t) \geq M(Q v, A B v, t / R)$ for all $v \in X$.

$\mathrm{M}(\mathrm{Qz}, \mathrm{ABz}, \mathrm{t}) \geq \mathrm{M}(\mathrm{z}, \mathrm{z}, \mathrm{t} / \mathrm{R})$

i.e $\mathrm{M}(\mathrm{Qz}, \mathrm{ABz}, \mathrm{t}) \geq 1$ 
Which implies that $\mathrm{Qz}=\mathrm{ABz}$.

Now we prove that $\mathrm{Pz}=\mathrm{z}$, by (6.32) with $\mathrm{a}=1$, we have,

$\mathrm{M}\left(\mathrm{Pz}, \mathrm{y}_{2 \mathrm{n}+1}, \mathrm{kt}\right)=\mathrm{M}\left(\mathrm{Pz}, \mathrm{Qx}_{2 \mathrm{n}+1}, \mathrm{kt}\right)$

$\geq M\left(y_{2 n}, y_{2 n+1}, t\right) * M(S T z, P z, t) * M\left(S T z, y_{2 n+1}, t\right) * M\left(y_{2 n}, P z, t\right) *$

$\mathrm{M}\left(\mathrm{y}_{2 \mathrm{n}}, \mathrm{STz}, \mathrm{t}\right)$.

Taking the limit as $\mathrm{n} \rightarrow \infty$, we have, $\mathrm{M}(\mathrm{Pz}, \mathrm{z}, \mathrm{kt}) \geq \mathrm{M}(\mathrm{Pz}, \mathrm{z}, \mathrm{t})$

Therefore by lemma 2.3, we have $\mathrm{Pz}=\mathrm{z}=\mathrm{STz}$.

Now, we show that $\mathrm{Q} z=\mathrm{z}$. In fact by (6.32) with $\mathrm{a}=1$ and (6.34), we have,

$\mathrm{M}\left(\mathrm{Px}_{2 \mathrm{n}}, \mathrm{Qz}, \mathrm{kt}\right) \geq \mathrm{M}(\mathrm{Bz}, \mathrm{Qz}, \mathrm{t}) * \mathrm{M}\left(\mathrm{STx}_{2 \mathrm{n}}, \mathrm{Px}_{2 \mathrm{n}}, \mathrm{t}\right) * \mathrm{M}\left(\mathrm{STx}_{2 \mathrm{n}}, \mathrm{Qz}, \mathrm{t}\right) *$

$\mathrm{M}\left(\mathrm{ABz}, \mathrm{Px}_{2 \mathrm{n}}, \mathrm{t}\right) * \mathrm{M}\left(\mathrm{ABz}, \mathrm{STx}_{2 \mathrm{n}}, \mathrm{t}\right)$

Taking the limit as $n \rightarrow \infty$, we have,

$\mathrm{M}(\mathrm{z}, \mathrm{Qz}, \mathrm{kt}) \geq \mathrm{M}(\mathrm{z}, \mathrm{Qz}, \mathrm{t})$

Therefore, by lemma 2.3, we have, $\mathrm{Qz}=\mathrm{z}=\mathrm{ABz}$.

Thus $\mathrm{Pz}=\mathrm{Qz}=\mathrm{ABz}=\mathrm{STz}=\mathrm{z}$.

By putting $\mathrm{x}=\mathrm{z}$ and $\mathrm{y}=\mathrm{Bz}$ with $\mathrm{a}=1$ in (6.32) using (6.34) and lemma 2.3, it is easy to see that $\mathrm{Bz}=\mathrm{z}$. Since $\mathrm{ABz}=\mathrm{z}$ therefore $\mathrm{Az}=\mathrm{z}$. By putting $\mathrm{x}=\mathrm{Tz}$ and $\mathrm{y}=$ $\mathrm{z}$ with $\mathrm{a}=1$ in (6.32) using (6.34) and lemma 2.3, it is easy to prove that

$\mathrm{Tz}=\mathrm{z}$. Since $\mathrm{STz}=\mathrm{z}$ we have $\mathrm{z}=\mathrm{STz}=\mathrm{Sz}$.

Therefore by combining the above results, we have,

$\mathrm{Az}=\mathrm{Bz}=\mathrm{Sz}=\mathrm{Tz}=\mathrm{Qz}=\mathrm{z}$.

That is $\mathrm{z}$ is the common fixed point of $\mathrm{A}, \mathrm{B}, \mathrm{S}, \mathrm{T}, \mathrm{P}$ and $\mathrm{Q}$. Uniqueness follows easily from (6.32).

This completes the proof.

\section{Conclusion}

Hence we produce very first result for common fixed point under the condition of R-weak commutativity without taking any function continuous on non complete fuzzy metric spaces which has not been proved earlier.

\section{ACKNOWLEDGEMENTS}

We are thankful to Prof. Sushil Sharma (Department of Mathematics, Govt. Madhav Science College, Ujjain (M.P.), India) for his helps during the preparation of this paper.

\section{References}

[1] Badard, R: Fixed point theorems for fuzzy number, Fuzzy Sets and Systems, 13(1984), 291-302.

[2] Chang, S.S., Cho, Y.J., Lee, B.S., Jung, J.S. and Kang, S.M.: Coincidence point and minimization theorems in fuzzy metric spaces, Fuzzy Sets and Systems 88(1) (1997), 119-128. 
[3] Cho, Y. J.: Fixed points in fuzzy metric spaces, J. Fuzzy Math., 5(4) (1997), 949- 962.

[4] Cho, Y.J.,Pathak, H.K., Kang, S.M. and Jung, J.S. : Common fixed points of compatible maps of type $(\beta)$ on fuzzy metric spaces, Fuzzy Sets and Systems, 93(1998), 99-111.

[5] Chugh, R. and Kumar, S.: Common fixed points for weakly compatible maps, Proc. Indian Acad. Sci. (Math. Sci.), 111(2) (2001), 241-247.

[6] Deng, Z. K. : Fuzzy pseudo metric spaces, J. Math. Anal. Appl., 86(1982), 74-95

[7] Erceg, M. A.:Metric spaces in fuzzy set theory, J. Math. Anal. Appl., 69(1979), 205-230.

[8] Fang, J. X.: On fixed point theorems in fuzzy metric spaces, Fuzzy Sets and Systems, 46(1992), 107-113.

[9] George, A. and Veeramani, P.: On some results in fuzzy metric spaces, Fuzzy Sets and Systems, 64(1994), 395-399.

[10] Grabiec, M.: Fixed point in fuzzy metric space, Fuzzy Sets and Systems, 27(1988), 385-389.

[11] Hadzic, O.: Fixed point theorems for multivalued mappings in some classes of fuzzy metric spaces, Fuzzy Sets and Systems, 29(1989), 115-125.

[12] Hadzic, O.: Fixed Point Theorems in Probabilistic Metric Spaces, Serbian Academy of Sciences and Arts, Institute of Mathematics, University of Novisad, Yugoslovia. 1995.

[13] Iseki, K.: Some applications of banach type contraction principles, Math. Sem. Notes. Kobe Univ., 4 (1976), 211-214.

[14] Istratescu, I.: A fixed point theorem for mappings with a probabilistic contractive iterates, Rev. Roumaire. Math. Pure Appl., 26(1981), 431-435.

[15] Jung, J. S., Cho, Y. J. and Kim, J. K.: Minimization theorems for fixed point theorems in fuzzy metric spaces and applications, Fuzzy Sets and Systems, 61(1994), 199-207. 
[16] Jung, J. S., Cho, Y. J., Chang, S. S. and Kang, S. M.: Coincidence theorems for set-valued mappings and Ekelands variational principle in fuzzy metric spaces, Fuzzy sets and Systems, 79(1996), 239-250.

[17] Jungck, G.: Commuting mappings and fixed points, Amer. Math. Monthly, 83(1976), 261-263.

[18] Jungck, G.: Commuting mappings and fixed points, Amer. Math. Monthly, 83(1976), 261-263.

[19] Jungck, G.: Common fixed points for commuting and compatible maps on compacta, Proc. Amer. Math. Soc., 103(1988), 977-983.

[20] Jungck, G., Murthy, P. P. and Cho, Y.J.: Compatible mappings of type (A) and common fixed points, Math.Japon., 38(2) (1993), 381-390.

[21] Jungck G., and Rhoades, B. E.: Fixed point for set valued functions without continuity, Ind. J. Pure Appl. Maths., 29(3)(1998), 227-238.

[22] Kaleva, O. and Seikkala, S.: On fuzzy metric spaces, Fuzzy Sets and Systems, 12(1984), 215-229.

[23] Kannan,R.: Some results on fixed points, Bull. Cal. Math. Soc., 60 (1968), 71-76.

[24] Kramosil, I. and Michalek, J.: Fuzzy metric and statistical metric spaces, Kybernetika, 11(1975), 336-344.

[25] Mishra, S. N., Sharma, N. and Singh, S. L.: Common fixed points of maps in fuzzy metric spaces. Internat. J. Math. Math. Sci., 17(1994), 253-258.

[26] Pant, R.P.: Common fixed points of non commuting mappings, J. Math. Anal. Appl., 188(1994), 436-440.

[27] Pathak, H.K.,Cho,Y.J., Chang,S.S. and Kang, S.M.: Compatible Mappings of Type (P), Rev. Res. Univ. Novisad to Apper.

[28] Rhoades,B.E.: A Comparison of Various definitions of contractive mappings, Trans, Amer. Math. Soc., 226(1977), 257-290.

[29] Rhoades, B.E.:Contractive definitions revisited, Contemp. math., 21 (1983), 313-334.

[30] Schweizer, B. and Sklar, A.: Statistical metric spaces, Pacific. J. Math., 10(1960), 313-334. 
[31] Sessa, S.: On weak commutativity condition of mappings in a fixed points considerations, Publ. Inst. Mat., 32(46) (1982), 149-153.

[32] Sessa, S., Rhoades, B.E. and Khan, M.S.: On common fixed points of compatible mappings in metric space and Banach space, Internat. J. Math.Math. Sci., 11(1988), 375-392.

[33] Sharma, Sushil and Deshpande, B.: Discontinuity and weak compatibility in fixed point consideration on non - complete fuzzy metric spaces, J. Fuzzy Math., Vol. 11 No. 2 (2003), 671-686.

[34] Singh, S.L.: Some common fixed pint theorems in L-spaces, Math. Sem. Notes. Kobe Univ., 7 (1979), 91-97.

[35] Singh, S.L. and Kasahara,S.: On some recent results on common fixed points, Indian J.Pure Appl., Maths., 13 (1982), 757-761, Corrigendum, 14 (1983), 1075.

[36] Singh, S.L. and Ram, B.: common fixed pints commuting mappings in 2 metric spaces, Math. Sem. Notes Kobe Univ., 10 (1982), 197-208.

[37] Sharma, Sushil : On fuzzy metric space, Southeast Asian Bull. Math.,Springer-Verlag, Vol. 6, No. 1 (2002), 145-157.

[38] Sharma, Sushil: Common fixed point theorems in fuzzy metric spaces, Fuzzy Sets and Systems. 125 (2001), 1-8.

[39] Sharma, Sushil and Deshpande, B.: Common fixed point of compatible maps of type $(\beta)$ on fuzzy metric space, Demonstratio Math., Vol. 35, No. 1 (2002), 165-174.

[40] Tivari, B.M.L. and Singh, S.L.: A. note on recent genralization of jungck contraction principle J. UPGC. Soc., 3 (1986), 13-19.

[41] Vasuki, R.: Common fixed point for R-weakly commuting maps in fuzzy metric spaces, Ind. J. Pure Appl. Math. 30(1999), 419-423.

[42] Zadeh, L.A.: Fuzzy Sets, Inform Contr., 8(1965), 338-353. 